\title{
Relationship between dry mouth, depression and systemic diseases in patients over 55 years of age from care homes and family homes
}

\section{Poszukiwanie związku pomiędzy objawami suchości, poczuciem depresji a chorobami ogólnoustrojowymi u badanych po 55. roku życia z domów pomocy społecznej i domów rodzinnych}

\author{
Katarzyna Barczak ${ }^{1 凶}$, Mirona Palczewska-Komsaํ, Aleksandra Wilk², Barbara Wiszniewska², Anna Jurczak², \\ Paulina Zabielska, Jadwiga Buczkowska-Radlińska
}

\author{
1 Pomorski Uniwersytet Medyczny w Szczecinie, Katedra i Zakład Stomatologii Zachowawczej i Endodoncji, al. Powstańców Wlkp. 72, 70-111 Szczecin \\ Pomeranian Medical University in Szczecin, Conservative Dentistry and Endodontics \\ 2 Pomorski Uniwersytet Medyczny w Szczecinie, Katedra i Zakład Histologii i Embriologii, al. Powstańców Wlkp. 72, 70-111 Szczecin \\ Pomeranian Medical University in Szczecin, Histology and Embryology Department \\ ${ }^{3}$ Pomorski Uniwersytet Medyczny w Szczecinie, Zakład Pielęgniarstwa Specjalistycznego, ul. Żołnierska 48, 71-210 Szczecin \\ Pomeranian Medical University in Szczecin, Department of Clinical Nursing \\ ${ }^{4}$ Pomorski Uniwersytet Medyczny w Szczecinie, Zakład Medycyny Społecznej i Zdrowia Publicznego, ul. Żołnierska 48, 71-210 Szczecin \\ Pomeranian Medical University in Szczecin, Department of Social Medicine and Public Health, Chair of Social Medicine \\ $\bowtie$ katarzyna.barczak@pum.edu.pl
}

\begin{abstract}
Introduction: Xerostomia (dry mouth, oral dryness) is the subjective sensation of dryness in the mouth. The gradual slight decrease in the secretion of saliva is physiologically related to aging of the body. Factors that predispose patients to the occurrence of dry mouth include systemic diseases, radiotherapy, anxiety and depression.

The aim of this study was to analyse the relationship between dry mouth, depression and systemic diseases in respondents living in nursing homes ( $\mathrm{NH}$ ) and family homes (FH).

Materials and methods: The study group comprised 226 respondents; 106 residents aged 55-101 years in two NH and 120 respondents living in FH. There were 110 men and 116 women. The study was based on the results of a diagnostic survey using an original questionnaire regarding general medical issues, and also the subjective feeling of dry mouth investigated with a standard Fox test. A shortened version of the Geriatric Depression Scale (GDS) was used to assess the wellbeing of patients and their state/sense of depression. The data obtained from the survey were analysed using Statistica 12 software (StatSoft Poland).
\end{abstract}

Results: On the basis of the information and an analysis of the medical documentation of the NH group of patients, isolated systemic illness was found in only a limited number of patients. High blood pressure combined with heart disease was most frequently noted in $\mathrm{NH}(26.4 \%)$ and $\mathrm{FH}$ patients (25\%). There was a significantly higher incidence of hypofunction and decreased secretion of saliva in $\mathrm{NH}$ patients (56.8\%) than in FH patients (41.6\%). No correlation between these symptoms and systemic diseases or depression was found in patients from either group. Conclusions: There was no correlation between the symptoms of dry mouth and the diagnosed systemic diseases in respondents from either group. The residents of $\mathrm{NH}$ were characterized by a worse mental state than those in FH. The symptoms of dry mouth were statistically significantly more frequent in residents of $\mathrm{NH}$ than in residents of FH. The residents of NH exhibiting worse mental state more often complained of a dry mouth sensation, however the difference was not statistically significant. Keywords: xerostomia; Fox test; elderly people; Geriatric Depression Scale; depression; systemic diseases.

\begin{abstract}
ABSTRAKT
Wstęp: Kserostomia jest subiektywnym objawem suchości w jamie ustnej, a zmniejszone wydzielanie śliny jest fizjologicznie związane z procesem starzenia się organizmu. Czynniki predysponujące do wystąpienia zespołu suchości jamy ustnej to: schorzenia ogólnoustrojowe i związana z tym farmakoterapia, radioterapia, stany lękowe i depresyjne.

Celem pracy było odnalezienie związku pomiędzy odczuciem suchości w jamie ustnej a poczuciem depresji i chorobami ogólnymi u badanych zamieszkujących domy pomocy społecznej (DPS) i domy rodzinne (DR).

Materiały i metody: Grupę badanych stanowiło 226 osób, w tym 106 zamieszkałych w dwóch DPS-ach i 120 w DR. Wśród nich było 110 mężczyzn i 116 kobiet. Wiek badanych zawierał się
\end{abstract}

w przedziale 55-101 lat. W pracy wykorzystano metodę sondażu diagnostycznego z wykorzystaniem autorskiego kwestionariusza, który uwzględniał zagadnienia ogólnomedyczne oraz część ukierunkowaną na subiektywne odczucia suchości w jamie ustnej. W tej części wykorzystano standaryzowane narzędzie formularz testu Foxa. Do oceny samopoczucia pacjentów i ich stanu/poczucia depresji posłużono się skróconą wersją Geriatrycznej Skali Depresji (GDS). Dane uzyskane w sondażu diagnostycznym poddano analizie statystycznej programem Statistica 12 (StatSoft Polska).

Wyniki: Na podstawie informacji podawanych przez badanych i analizę ich dokumentacji medycznej (dotyczy osób z DPS) u niewielkiego odsetka z obu grup stwierdzono izolowane choroby ogólnoustrojowe. Pacjenci najczęściej chorowali na nadciśnienie 
tętnicze w połączeniu z chorobą serca (odpowiednio DPS - 26,4\% i DR - 25\%). Statystycznie istotne jest częstsze występowanie objawów suchości jamy ustnej w postaci hipofunkcji i zmniejszonego wydzielania śliny u pacjentów z DPS niż u osób z DR (56,8\% vs. 41,6\%). Nie stwierdzono zależności między zmniejszonym wydzielaniem śliny a chorobami ogólnoustrojowych oraz objawami depresji.

Wnioski: Nie stwierdzono zależności pomiędzy objawami suchości w jamie ustnej a stwierdzonymi chorobami ogólnymi u badanych osób z obu grup. Pacjenci z DPS charakteryzowali się gorszym stanem psychicznym niż badani z DR. U osób z DPS częściej występowały objawy suchości jamy ustnej niż u osób z DR (różnica statystycznie istotna). Pacjenci z DPS, którzy charakteryzowali się gorszym stanem psychicznym, częściej skarżyli się na odczucie suchości w jamie ustnej. Nie była to jednak różnica istotna statystycznie.

Słowa kluczowe: kserostomia; test Foxa; ludzie starsi; Geriatryczna Skala Depresji; depresja; choroby ogólnoustrojowe.

\section{INTRODUCTION}

Xerostomia (dry mouth, oral dryness) is the subjective sensation of dryness in the mouth. Two types of xerostomia can be distinguished: xerostomia vera, primaria and xerostomia spuria, symptomatica. The former (xerostomia vera) is associated with a decreased secretion of saliva by the salivary glands with clinically unaltered mucosa (type I) or associated atrophy of the mucosa (type II), and with visible pathological alterations in the salivary glands. The second type is seen in patients reporting dryness and a burning sensation in the mucous membrane, even though the salivary glands continue to function normally $[1,2]$. It should also be noted that xerostomia is not classified as a separate disease, but as a symptom of various accompanying local and systemic diseases $[1,2,3,4]$. In general, it is difficult to assess the incidence of xerostomia in the population due to differences in diagnostic criteria. However, it is estimated that about $10 \%$ of the population is affected by xerostomia, and about $25 \%$ of these are older than 65 years [2]. Various factors including body hydration, body position, exposure to light, circadian and annual rhythm, body weight and psychological condition can affect the amount of saliva $[1,2]$. A gradual slight decrease in the secretion of saliva is physiologically related to aging of the body, which may lead to xerostomia and atrophy of the mucous membrane [5]. Furthermore, it is known that women have a greater propensity for dry mouth syndrome than men $[2,6]$. Regardless of age and sex, xerostomia is seen in people suffering from chronic systemic diseases such as collagen diseases, diabetes, sarcoidosis, Alzheimer's disease, disorders of the excretory system, graft-versus-host disease, HIV/AIDS, and diseases of the salivary glands (acute and chronic inflammation) and kidneys, cysts, and tumours. Other factors that predispose patients to the occurrence of dry mouth include radiotherapy of the head and neck, oral sensory dysfunction, anxiety and depression. It should also be noted that there are about 400 drugs that contribute to the reduction of salivary secretion (including anticholinergics, antidepressants, tranquilizers, diuretics, antihypertensive drugs, antiarrhythmic drugs, cytotoxic drugs, antiepileptic drugs, Parkinson's disease drugs, antihistamines and analgesics) $[2,7,8,9]$.

Subjective tests followed by objective studies are needed to assess the amount of saliva being produced. The subjective

\section{WSTĘP}

Kserostomia (dry mouth, mouth dryness, oral dryness) jest subiektywnym objawem suchości w jamie ustnej. Rozróżnia się kserostomię prawdziwą (xerostomia vera, primaria) i rzekomą (xerostomia spuria, symptomatica). Pierwszy rodzaj kserostomii związany jest ze zmniejszonym wydzielaniem gruczołów ślinowych przy niezmienionej klinicznie błonie śluzowej (typ I) lub z towarzyszącym jej zanikiem (typ II) i widocznymi zmianami patologicznymi w gruczołach ślinowych. Z kolei drugi rodzaj kserostomii jest obserwowany u pacjentów subiektywnie odczuwających suchość i pieczenie błony śluzowej przy zachowaniu prawidłowej czynności ślinianek [1, 2]. Należy zauważyć, że kserostomia nie jest klasyfikowana jako oddzielna jednostka chorobowa, ale jako objaw towarzyszący różnym schorzeniom miejscowym i ogólnym $[1,2,3,4]$. Ze względu na różnice w kryteriach diagnostycznych trudno jest ocenić częstość występowania kserostomii w populacji. Szacuje się, że ok. 10\% społeczeństwa jest dotknięta tą przypadłością, z czego $25 \%$ to osoby w wieku $>65$ lat [2]. Na ilość wydzielanej śliny u zdrowego człowieka wpływ mają różne czynniki, np. stopień nawodnienia organizmu, pozycja ciała, ekspozycja na światło, rytm dobowy i roczny, waga ciała, oddziaływanie psychiczne [1, 2]. Spadek wydzielania śliny jest fizjologicznie związany z procesem starzenia organizmu. Wraz z wiekiem obserwowany jest stopniowy, nieznaczny zanik gruczołów ślinowych, który może prowadzić do wystąpienia kserostomii oraz zmiany atroficznej błony śluzowej [5]. Ponadto stwierdzono, że kobiety wykazują większą predylekcję do zespołu suchości jamy ustnej niż mężczyźni $[2,6]$. Niezależnie od wieku i płci kserostomia jest obserwowana u osób cierpiących na przewlekłe choroby układowe, takie jak: kolagenozy, cukrzyca, sarkoidoza, choroba Alzheimera, zaburzenia układu wydalniczego, choroba przeszczep przeciwko gospodarzowi, HIV/AIDS oraz choroby gruczołów ślinowych (ostre i przewlekłe zapalenia, kamica, torbiele, guzy nowotworowe). Inne czynniki predysponujące do wystąpienia zespołu suchości jamy ustnej to: radioterapia okolicy głowy i szyi, dysfunkcja czuciowa jamy ustnej, stany lękowe i depresyjne. Należy również zwrócić uwagę, że istnieje ok. 400 leków, które przyczyniają się do redukcji wydzielania śliny (np. antycholinergiczne, antydepresyjne, uspokajające, diuretyki, obniżające ciśnienie krwi, antyarytmiczne, cytotoksyczne, przeciwpadaczkowe, w leczeniu choroby Parkinsona, antyhistaminowe, przeciwbólowe) [2, 7, 8, 9]. 
test includes a general interview, a dental interview, and the Fox test, whereas the objective studies include a wetting test (mirror test, modified Schrimer test, wafer test), measurement of resting and stimulated salivation, biochemical analysis of saliva, serum tests, salivary gland imaging, sialography, scintigraphy, and histopathological studies. An important advantage of the objective tests is their high sensitivity; however, most are time-consuming, invasive, and more complicated than the subjective studies. The subjective tests, in turn, are simple noninvasive diagnostic tools, and their positive result for dry mouth requires further objective diagnostic tests $[1,2,4]$.

Dry mucosa is less resistant to irritants and its healing is impaired. Ulcers, candidiasis, and stomatopathy can develop, making the use or adaptation of prosthetic restorations difficult $[4,10,11]$. Eating disorders are also associated with poorer taste perception and lack of appetite, which directly affects general condition and nutritional deficiencies $[4,12,13]$. The dental aspects of dryness include an increased risk of dental caries (mainly acute), periodontal inflammation, and halitosis. Another discomfort of the oral cavity is a burning sensation, which can lead to various depressive states and decreased quality of life $[4,14,15]$.

The aim of this study was to analyse the relationship between sensation of dry mouth, depression and systemic diseases in residents of nursing homes $(\mathrm{NH})$ and family homes (FH).

\section{MATERIALS AND METHODS}

\section{Characteristics of study group}

The study group consisted of 226 respondents, comprising 106 patients living in $2 \mathrm{NH}$ and 120 respondents living in FH in Szczecin, who had undergone treatment in the primary health care outpatients clinic at Podgórna Street and in the Conservative Dentistry Outpatient Clinic of the Pomeranian Medical University in Szczecin. Patients included in the study consented in writing to participate in the research.

The clinical study was conducted on 226 patients, and the diagnostic survey on 202 patients. In the case of $24 \mathrm{NH}$ residents, the diagnostic survey was abandoned in full or partially due to existing chronic systemic diseases or impaired verbal contact. The survey was completed by patients individually or, in several cases, with the assistance of the author of the questionnaire, after obtaining the answers from the respondent.

The study group comprised 110 men (50 men from $\mathrm{NH}$, 63 from $\mathrm{FH}$ ) and 116 women ( 56 from NH, 57 from $\mathrm{FH}$ ). The age of the $\mathrm{NH}$ patients ranged from 55-101 years (mean 73.8 \pm 10.8 ), while the ages of the FM patients was $55-85$ years (mean $67.4 \pm 8.8$ ). The study was approved by the Bioethics Committee of the Pomeranian Medical University in Szczecin (No. BN-001/137/07).

\section{The diagnostic survey}

A survey consisting of both general medical and dental questions related to subjective feeling of dry mouth $[2,4,8]$ was
Aby ocenić ilość wydzielanej śliny, wykonuje się w pierwszej kolejności badania subiektywne, a następnie obiektywne. Do tych pierwszych zalicza się: wywiad ogólnolekarski, wywiad stomatologiczny oraz test Foxa. Z kolei do badań subiektywnych należą: test zwilżania jamy ustnej (test lusterkowy, zmodyfikowany, Schrimera, opłatkowy), pomiar szybkości wydzielanej śliny spoczynkowej i stymulowanej, analiza biochemiczna śliny, badania surowicy krwi, obrazowanie gruczołów ślinowych, sialografia, scyntografia i badanie histomorfotyczne. Niewątpliwą zaletą badań obiektywnych jest ich duża czułość, jednakże większość z nich wymaga znacznej ilości czasu. Zwykle są inwazyjne i bardziej skomplikowane w porównaniu do badania subiektywnego. $Z$ kolei badanie subiektywne jest prostym, nieinwazyjnym narzędziem diagnostycznym, a jego dodatni wynik w kierunku suchości jamy ustnej skłania do dalszej diagnostyki badaniami obiektywnymi $[1,2,4]$.

Sucha błona śluzowa jest mniej odporna na czynniki drażniące i charakteryzuje się gorszym przebiegiem procesu gojenia. Przez nią powstają owrzodzenia, kandydozy i stomatopatie, które utrudniają użytkowanie bądź adaptację do uzupełnień protetycznych $[4,10,11]$. Prowadzi to do zaburzeń w przyjmowaniu pokarmów, związanych również z gorszym odczuwaniem smaku i brakiem apetytu, a to wpływa bezpośrednio na stan ogólny i niedobory pokarmowe $[4,12,13]$. Stomatologiczny aspekt suchości to zwiększone ryzyko występowania próchnicy, głównie ostrej, stanów zapalnych przyzębia i fetor ex ore. Dyskomfort w jamie ustnej to, oprócz suchości, również pieczenie, które z kolei może wpływać na obniżenie nastroju, pojawienie się stanów depresyjnych i jednocześnie prowadzi do spadku jakości życia [4, 14, 15].

Celem pracy było poszukiwanie związku pomiędzy odczuciem suchości w jamie ustnej a poczuciem depresji i chorobami ogólnymi u badanych zamieszkujących domy pomocy społecznej (DPS) i domy rodzinne (DR).

\section{MATERIAŁY I METODY}

\section{Charakterystyka badanych}

Grupę badanych stanowiło 226 osób, w tym 106 zamieszkałych w 2 DPS-ach w Gryficach i 120 zamieszkujących DR na terenie Szczecina, którzy zgłaszali się na leczenie w ramach podstawowej opieki zdrowotnej do Przychodni Medycyny Rodzinnej przy ul. Podgórnej oraz do Poradni Stomatologii Zachowawczej Uniwersyteckiej Kliniki Stomatologicznej Pomorskiego Uniwersytetu Medycznego w Szczecinie. Wszyscy uczestnicy badania wyrazili pisemną zgodę na wzięcie w nim udziału.

Badaniem klinicznym objęto 226 pacjentów, a badaniem ankietowym 202. W przypadku 24 pacjentów z DPS-ów odstąpiono częściowo lub całkowicie od przeprowadzenia badania ankietowego ze względu na przewlekłe schorzenia ogólnoustrojowe lub utrudniony kontakt werbalny. Kwestionariusz badania ankietowego pacjenci wypełniali osobiście lub wypełniał go autor po zadaniu pytania badanemu.

Wśród badanych osób było 110 mężczyzn (DPS: 50, DR: 63) i 116 kobiet (DPS: 56, DR: 57). Wiek pacjentów z DPS-ów znajdował się w przedziale 55-101 lat, a jego średnia wartość była 
given to the patients. A shortened version of the Geriatric Depression Scale (GDS) by Yesavage (1983) was used to assess the wellbeing of patients and their state/sense of depression [14]. Patients responded to 15 questions by circling either YES or NO. Patients were instructed to give information from the past 2 weeks. According to the key of depressive points, patients were classified following the recommendations of the author of the scale: $0-5$ points - no sense of depression, 6-15 points - a sense of depression, with increasing severity. Participation in the study was anonymized.

The general medical questions concerned the presence of systemic diseases were established on the grounds of available medical information provided by the respondents, an analysis of medical history, and data on the use of medications. The dental part of the interview concerned the subjective sensation of oral cavity dryness and a Fox test. This test completed 103 men ( $40 \mathrm{NH}$ and $63 \mathrm{FH}$ ) and 105 women (48 $\mathrm{NH}$ and $57 \mathrm{FH}$ ) and $18 \mathrm{NH}$ patients did not complete the survey regarding the Fox test because of chronic somatic disorders. The Fox test, which is the most widely recommended for xerostomia history in both clinical and research work [2, $4,8]$, consists of 10 questions regarding the subjective sensation of dry mouth:

1. Do you feel dry mouth at night or when you wake up?

2. Do you feel dry mouth during the day?

3. Do you keep a glass of water next to the bed?

4. Do you need to drink while swallowing dry food?

5. Do you experience a sensation of dry mouth when eating?

6. Do you have any difficulties swallowing food?

7. Do you use chewing gum every day to get rid of the sensation of dry mouth?

8. Do you eat hard candy or mints every day to get rid of the sensation of dry mouth?

9. Does the amount of saliva present in your mouth seem to be too small, too large, or have you not noticed anything concerning the amount of saliva?

10. Do you need to frequently wet your mouth?

On the basis of the answers to these questions, the severity of disorders associated with impaired secretion of saliva can be inferred. In addition, it was assumed that YES to 3 or 4 of the question - numbers $4,5,6$, and 9, may indicate hypofunction and reduced saliva secretion [2, 9].

\section{Statistical analysis}

Patients were divided into groups according to sex and place of residence. The data obtained from the survey were analysed with statistical methods using Statistica 12 (StatSoft Poland). The normality of distribution for quantitative variables was tested using a Shapiro-Wilk test. A $\chi^{2}$ independence test with a Yates correction or a Fisher exact test for small groups was used to compare variables from 2 independent groups. The admissible type I probability error (significance level) was adopted at $\mathrm{p}=0.05$. równa 73,8 $\pm 10,8$. Z kolei wiek badanych z DR-u wynosił 55-85 lat, a jego średnia wartość była równa 67,4 $\pm 8,8$.

Na przeprowadzenie badań uzyskano zgodę Komisji Bioetycznej Pomorskiego Uniwersytetu Medycznego w Szczecinie, nr BN-001/137/07.

\section{Sondaż diagnostyczny}

Pacjenci zostali poddani badaniu ankietowemu. Kwestionariusz ankiety składał się z 2 części: wywiadu ogólnomedycznego i wywiadu stomatologicznego ukierunkowanego na subiektywne odczucia suchości w jamie ustnej $[2,4,8]$. Do oceny samopoczucia pacjentów i ich stanu/poczucia depresji posłużono się skróconą wersją Geriatrycznej Skali Depresji (Geriatric Depression Scale - GDS) wg Yesavage’a [14]. Pacjenci odpowiadali samodzielnie na 15 pytań, zakreślając wybraną odpowiedź: TAK lub NIE i mieli oni wziąć pod uwagę 2 tygodnie poprzedzające badanie. Według klucza punktów depresyjnych ankietowanych zakwalifikowano do 2 grup, zgodnie z zaleceniami autora skali: 0-5 pkt. - bez poczucia depresji, 6-15 pkt. - poczucie depresji o rosnącym nasileniu. Udział w badaniu był anonimowy.

Wywiad ogólnomedyczny obejmował obecność chorób ogólnych, stwierdzonych na podstawie informacji podawanych przez badanych i analizy ich dotychczasowej dokumentacji medycznej, oraz dane związane z ewentualnie przyjmowanymi lekami. Stomatologiczna część wywiadu dotyczyła subiektywnego odczucia suchości ze strony jamy ustnej, a także zawierała pytania z testu Foxa. Wśród ankietowanych testem Foxa było 103 mężczyzn (DPS: 40, DR: 63) oraz 105 kobiet (DPS: 48, DR: 57). Osiemnaście osób z DPS-ów nie wypełniło części badania dotyczącej testu Foxa ze względu na zaawansowane lub przewlekłe schorzenia somatyczne.

Obecnie najbardziej znaną i polecaną formą wywiadu w kierunku kserostomii, zarówno w badaniach klinicznych, jak i pracach badawczych, jest test Foxa [2, 4, 8]. Składa się on z 10 pytań dotyczących subiektywnych odczuć suchości jamy ustnej:

1. Czy odczuwa Pan/Pani suchość w jamie ustnej w nocy lub po przebudzeniu?

2. Czy odczuwa Pan/Pani suchość w jamie ustnej w ciągu dnia?

3. Czy trzyma Pan/Pani szklankę wody przy łóżku?

4. Czy popija Pan/Pani przy połykaniu suchego pożywienia?

5. Czy suchość jamy ustnej występuje u Pana/Pani podczas spożywania posiłku?

6. Czy ma Pan/Pani trudności w połykaniu pożywienia?

7. Czy żuje Pan/Pani gumę codziennie, aby pozbyć się odczucia suchości w jamie ustnej?

8. Czy codziennie używa Pan/Pani twardych cukierków owocowych lub miętowych, aby pozbyć się odczucia suchości jamy ustnej?

9. Czy ilość śliny występującej w jamie ustnej wydaje się Panu/Pani zbyt mała, za duża lub nie zauważa Pan/Pani tego?

10. Czy odczuwa Pan/Pani potrzebę częstego zwilżania jamy ustnej?

Na podstawie udzielonych odpowiedzi na powyższe pytania można wnioskować o stopniu nasilenia dolegliwości związanych z zaburzeniami wydzielania śliny. Ponadto przyjęto, że odpowiedź twierdząca na 3 lub 4 pytania o numerze 4, 5, 6, 9 może świadczyć o hipofunkcji i zmniejszonym wydzielaniu śliny [2, 9]. 


\section{RESULTS}

The most common diseases in both groups of subjects are shown in Table 1. Isolated systemic illness was found in only a limited number of patients where high blood pressure combined with heart disease was noted; this constituted $26.4 \%$ of the NH group and $25 \%$ of the FH group. In addition, hypertension combined with heart disease and osteoarticular disorders occurred significantly more often in $\mathrm{NH}$ patients than in $\mathrm{FH}$ patients $(\mathrm{p}<0.05)$.

Positive answers to the Fox test were given by 88 patients from $\mathrm{NH}$ and 120 from $\mathrm{FH}$. In comparison with $\mathrm{FH}$ patients, $\mathrm{NH}$ patients suffered from dryness of the mouth during the day and during meals, and felt uncomfortable because of hyposalivation statistically significantly more often than FH patients. In addition, $\mathrm{NH}$ patients gave positive answers significantly more often to questions 4, 5, 6, $9(4 \mathrm{~A})$ in the Fox test than FH patients. On the other hand, FH patients significantly more often answered YES to the question about drinking with dry foods and eating candies to compensate for dry mouth as compared to NH patients (Tab. 2).

The analysis of positive answers in the Fox test's questions numbers 4, 5, 6, and 9, which are associated with hyposalivation in patients suffering from the most common systemic diseases (hypertension, heart disease, diabetes, and bone and joint diseases), did not show any significant differences in elderly patients (Tab. 3).

\section{Analiza statystyczna wyników}

Wszystkich pacjentów podzielono na 2 grupy w zależności od płci oraz miejsca zamieszkania (DR, DPS). Dane uzyskane w badaniach ankietowych poddano analizie statystycznej programem Statistica 12, StatSoft Polska. Za pomoca testu Shapiro-Wilka zbadano zgodność rozkładu badanych zmiennych ilościowych z rozkładem normalnym. Porównań badanych zmiennych dla 2 grup niezależnych dokonano, stosując test niezależności $\chi^{2} z$ poprawką Yatesa lub test dokładny Fishera dla małych grup. Jako dopuszczalne prawdopodobieństwo błędu pierwszego rodzaju (poziom istotności testu) przyjęto $p=0,05$.

\section{WYNIKI}

W tabeli 1 przedstawiono najczęściej występujące schorzenia u badanych w obu grupach. U niewielkiego odsetka badanych z obu grup stwierdzono izolowane choroby ogólnoustrojowe. Najczęściej pacjenci z DPS-ów i DR-ów chorowali na nadciśnienie tętnicze w połączeniu z chorobą serca (odpowiednio $26,4 \%$ i $25 \%)$. Ponadto nadciśnienie tętnicze w połączeniu z chorobą serca i schorzeniami kostno-stawowymi występowało istotnie częściej u pacjentów z DPS-ów niż u pacjentów z DR-ów ( $<<0,05)$.

Wyniki odpowiedzi twierdzących w teście Foxa odnotowano u pacjentów z DPS-ów $(n=88)$ i DR-ów ( $\mathrm{n}=120)$. Mieszkańcy DPS-ów w porównaniu do badanych z DR-ów statystycznie istotnie częściej deklarowali odczuwanie suchości

TABLE 1. Systemic disease in patients of both groups

TABELA 1. Schorzenia ogólnoustrojowe u pacjentów w obu badanych grupach

\begin{tabular}{|c|c|c|c|c|c|}
\hline \multirow{2}{*}{$\begin{array}{l}\text { Type of disorder } \\
\text { Rodzaj schorzenia }\end{array}$} & \multicolumn{2}{|c|}{ NH / DPS } & \multicolumn{2}{|c|}{ FH / DR } & \multirow{2}{*}{$\begin{array}{c}\text { Significant difference } \\
\text { Istotność statystyczna } \\
\text { NH vs. FH } \\
\text { DPS vs. DR }\end{array}$} \\
\hline & $n / N$ & $\%$ & $n / N$ & $\%$ & \\
\hline$A, B, C, D$ & $6 / 106$ & 5.7 & $4 / 120$ & 3.3 & NS \\
\hline$A, B, C$ & 4/106 & 3.8 & $12 / 120$ & 10.0 & NS \\
\hline$A, C, D$ & $2 / 106$ & 1.9 & $1 / 120$ & 0.8 & NS \\
\hline$B, C, D$ & $1 / 106$ & 0.9 & $2 / 120$ & 1.7 & NS \\
\hline$A, B$ & $28 / 106$ & 26.4 & $30 / 120$ & 25.0 & NS \\
\hline$A, C$ & $2 / 106$ & 1.9 & $2 / 120$ & 1.7 & NS \\
\hline$A, D$ & $3 / 106$ & 2.8 & $6 / 120$ & 5.0 & NS \\
\hline$B, D$ & $1 / 106$ & 0.9 & $2 / 120$ & 1.7 & NS \\
\hline C, D & $1 / 106$ & 0.9 & $21 / 120$ & 17.5 & NS \\
\hline$A$ & $8 / 106$ & 7.5 & $9 / 120$ & 7.5 & NS \\
\hline B & $10 / 106$ & 9.4 & $21 / 120$ & 17.5 & NS \\
\hline$C$ & 4/106 & 3.8 & $1 / 120$ & 0.8 & NS \\
\hline $\mathrm{D}$ & $11 / 88$ & 10.4 & $6 / 120$ & 5.0 & NS \\
\hline- & $12 / 88$ & 11.3 & $11 / 120$ & 9.2 & NS \\
\hline
\end{tabular}

A - hypertension; $\mathrm{B}$ - heart disease; $\mathrm{C}$ - diabetes; $\mathrm{D}$ - bone and joint diseases; $\mathrm{NH}$ - patients from nursing homes; $\mathrm{FH}$ - patients from family homes; $\mathrm{n}$ - number of patients with systemic diseases; $\mathrm{N}$ - total number of examined patients

A - nadciśnienie; B - choroba serca; C - cukrzyca; D - schorzenia kostno-stawowe; DPS - pacjenci z domu pomocy społecznej; DR - pacjenci z domów rodzinnych; n - liczba pacjentów ze schorzeniami ogólnymi; N - liczba wszystkich badanych pacjentów 
TABLE 2. The results of Fox test in nursing homes and family homes patients

TABELA 2. Uzyskana punktacja testu Foxa u pacjentów z domów pomocy społecznej i domów rodzinnych

\begin{tabular}{|c|c|c|c|c|c|}
\hline \multirow{2}{*}{$\begin{array}{c}\text { Fox test } \\
\text { Punktacja testu Foxa }\end{array}$} & \multicolumn{2}{|c|}{ NH / DPS } & \multicolumn{2}{|c|}{ FH / DR } & \multirow{2}{*}{$\begin{array}{c}\text { Significant difference } \\
\text { Istotność statystyczna } \\
\text { NH vs. FH } \\
\text { DPS vs. DR }\end{array}$} \\
\hline & $n / N$ & $\%$ & $n / N$ & $\%$ & \\
\hline 1 & $50 / 88$ & 56.8 & $68 / 120$ & 56.7 & NS \\
\hline 2 & $42 / 88$ & 47.7 & $40 / 120$ & 33.3 & $p<0.05$ \\
\hline 3 & $45 / 88$ & 51.1 & $63 / 120$ & 52.5 & NS \\
\hline 4 & $25 / 88$ & 28.4 & $54 / 120$ & 45.0 & $p<0.05$ \\
\hline 5 & $25 / 88$ & 28.4 & $19 / 120$ & 15.8 & $p<0.05$ \\
\hline 6 & $27 / 88$ & 30.7 & $29 / 120$ & 24.4 & NS \\
\hline 7 & $2 / 88$ & 2.3 & $5 / 120$ & 4.2 & NS \\
\hline 8 & $17 / 88$ & 19.3 & $40 / 120$ & 33.3 & $p<0.05$ \\
\hline 9 & $57 / 88$ & 64.8 & $54 / 120$ & 45.0 & $p<0.01$ \\
\hline 10 & $52 / 88$ & 59.1 & $56 / 120$ & 46.7 & NS \\
\hline $4,5,6,9$ & $7 / 88$ & 8.0 & $9 / 120$ & 7.5 & NS \\
\hline $4,5,6$ & $8 / 88$ & 9.0 & $10 / 120$ & 8.3 & NS \\
\hline $4,5,9$ & $11 / 88$ & 12.5 & $10 / 120$ & 8.3 & NS \\
\hline $4,6,9$ & $11 / 88$ & 12.5 & $11 / 120$ & 9.2 & NS \\
\hline $5,6,9$ & $13 / 88$ & 14.8 & $10 / 120$ & 8.3 & NS \\
\hline $4 \mathrm{~A}$ & $50 / 88$ & 56.8 & $50 / 120$ & 41.6 & $p<0.05$ \\
\hline
\end{tabular}

$\mathrm{NH}$ - patients from nursing homes; $\mathrm{FH}$ - patients from family homes; $\mathrm{n}$ - number of patients who responded positively to the question in the Fox test; $\mathrm{N}$ - total number of examined patients; 4A - number of patients who answered YES 3 or 4 times to questions 4, 5, 6 or 9

DPS - pacjenci z domu pomocy społecznej; DR - pacjenci z domów rodzinnych; $n$ - liczba pacjentów, która pozytywnie odpowiedziała na pytanie w teście Foxa; N - liczba wszystkich badanych pacjentów; 4A - liczba pacjentów, którzy dali 3 lub 4 pozytywne odpowiedzi na pytania nr 4, 5, 6, 9

TABLE 3. Fox test answers for patients from both groups, by concomitant diseases

TABELA 3. Test Foxa u pacjentów z obu badanych grup w zależności od współtowarzyszących chorób ogólnych

\begin{tabular}{|c|c|c|c|c|c|}
\hline \multirow{3}{*}{ Type of disease / Rodzaj schorzenia } & \multicolumn{4}{|c|}{$\begin{array}{l}\text { YES to questions 4, 5, 6, } 9 \text { in Fox test } \\
\text { Pozytywna odpowiedź na pytanie nr 4, 5, 6, } 9 \text { w teście Foxa }\end{array}$} & \multirow{3}{*}{$\begin{array}{c}\text { Significant difference } \\
\text { Istotność statystyczna } \\
\text { NH vs. FH } \\
\text { DPS vs. DR } \\
\end{array}$} \\
\hline & \multicolumn{2}{|c|}{ NH / DPS } & \multicolumn{2}{|c|}{ FH / DR } & \\
\hline & $\mathrm{n} / \mathrm{N}$ & $\%$ & $n / N$ & $\%$ & \\
\hline Hypertension/Nadciśnienie & $3 / 7$ & 42.8 & $4 / 9$ & 44.4 & NS \\
\hline Diabetes/Cukrzyca & $7 / 7$ & 100 & $7 / 9$ & 77.7 & NS \\
\hline $\begin{array}{l}\text { Bone and joint diseases / } \\
\text { Choroby układu kostno-stawowego }\end{array}$ & $4 / 7$ & 57.1 & $4 / 9$ & 44.4 & NS \\
\hline
\end{tabular}

$\mathrm{NH}$ - patients from nursing homes; FH - patients from family homes; $\mathrm{n}$ - number of patients who answered YES to questions 4, 5, 6,9 of the Fox test; $\mathrm{N}$ - total number of examined patients

DPS - pacjenci z domu pomocy społecznej; DR - pacjenci z domów rodzinnych; n - liczba pacjentów, która pozytywnie odpowiedziała na pytanie 4, 5, 6 i 9 w teście Foxa; $\mathrm{N}$ - liczba wszystkich badanych pacjentów

Patients living in FH (60\%) did not report symptoms of depression any more often than subjects living in NH (20.7\%), and a sense of depression with increasing severity was significantly more frequent in subjects living in NH (79.3\%) than in those living in FH (40\%) - Table 4.

In addition, we analyzed the relationship between the occurrence of the feeling of depression in $\mathrm{NH}$ and $\mathrm{FH}$ patients who answered YES to questions 4, 5, 6, and 9 in the Fox test (sensation of dry mouth and hyposalivation). No significant differences were noted in this regard. A greater number of the w jamie ustnej w ciągu dnia, w czasie spożywania posiłków oraz odczuwali dyskomfort z powodu zbyt małej ilości wydzielanej śliny. Co więcej, pacjenci z DPS-ów istotnie częściej odpowiadali twierdząco na 3 lub 4 pytania $(4 \mathrm{~A})$ w teście Foxa. Z kolei pacjenci z DR-ów istotnie częściej odpowiadali twierdząco na pytanie dotyczące popijania suchych posiłków oraz konieczności jedzenia cukierków w celu pozbycia się suchości w jamie ustnej w porównaniu do pacjentów z DPS-ów (tab. 2).

Analiza zależności odpowiedzi pozytywnych w teście Foxa na pytania 4, 5, 6 i 9, mogących świadczyć o hipofunkcji 
TABLE 4. Numbers and percentages of patients without depressive disorders (GDS $\leq 5$ ) and with depressive disorders (GDS $>5 \leq 15$ ) in both studied groups TABELA 4. Liczba i odsetek pacjentów bez zaburzeń depresyjnych (GDS $\leq 5)$ i z zaburzeniami depresyjnymi (GDS $>5 \leq 15)$ w obu badanych grupach

GDS points / Wartości punktów w skali GDS

$\leq 5$

$>5 \leq 15$

\begin{tabular}{ccccccccc}
\hline & NH / DPS & \multicolumn{2}{c}{ FH / DR } & \multicolumn{2}{c}{ NH / DPS } & & FH / DR \\
\hline $\mathbf{n}$ & $\%$ & $\mathbf{n}$ & $\%$ & $\mathbf{n}$ & $\%$ & $\mathbf{n}$ & \% \\
\hline 17 & $20.7^{*}$ & 72 & $60.0^{*}$ & 65 & $79.3^{*}$ & 48 & $40.0^{*}$ \\
\hline
\end{tabular}

$* \mathrm{p}<0.05$

$\mathrm{NH}$ - patients from nursing homes; $\mathrm{FH}$ - patients from family homes

DPS - pacjenci z domu pomocy społecznej; DR - pacjenci z domów rodzinnych

TABLE 5. Fox test responses of patients from both groups, by GDS score

TABELA 5. Test Foxa u pacjentów z obu badanych grup w zależności od punktacji GDS

\begin{tabular}{|c|c|c|c|c|c|}
\hline \multirow{3}{*}{$\begin{array}{l}\text { Points obtained in the GDS } \\
\text { Punktacja uzyskana w GDS }\end{array}$} & \multicolumn{4}{|c|}{$\begin{array}{l}\text { YES to questions } 4,5,6,9 \text { in the Fox test } \\
\text { Pozytywna odpowiedź na pytanie nr 4, 5, 6, } 9 \text { w teście Foxa }\end{array}$} & \multirow{3}{*}{$\begin{array}{c}\begin{array}{c}\text { Significant difference } \\
\text { Istotność statystyczna }\end{array} \\
\text { NH vs FH } \\
\text { DPS vs DR }\end{array}$} \\
\hline & \multicolumn{2}{|c|}{ NH / DPS } & \multicolumn{2}{|c|}{ FH / DR } & \\
\hline & $n / N$ & $\%$ & $n / N$ & $\%$ & \\
\hline $0-5$ & $1 / 7$ & 14.3 & $3 / 9$ & 33.3 & $\mathrm{NS}, \mathrm{p}=0.58$ \\
\hline 11-15 & $5 / 7$ & 71.4 & $3 / 9$ & 33.3 & $\mathrm{NS}, \mathrm{p}=0.31$ \\
\hline
\end{tabular}

$\mathrm{NH}$ - patients from nursing homes; $\mathrm{FH}$ - patients from family homes

DPS - pacjenci z domu pomocy społecznej; DR - pacjenci z domów rodzinnych

patients who scored 0-10 points on the GDS scale were FH patients, with NH patients more often scoring 11-15 points (Tab. 5). Patients from NH characterised by poor mental condition reported the feeling of dry mouth more often - however, the difference was not statistically significant.

\section{DISCUSSION}

A study by Stawska, who examined 135 NH residents aged 66-87 years from Szczecin and the surrounding areas of Poland, indicates that $62.9 \%$ of those patients complained of dry mouth [12]. These results correspond with our study, in which $56.8 \%$ of $\mathrm{NH}$ patients suffered from hyposalivation. Porter et al. [13] reported a slightly lower percentage of people with dry mouth syndrome in British $\mathrm{NH}$ residents aged 65-100. The patients were divided into 2 groups according to the presence of or total absence of teeth. Dryness of the mouth was prevalent in both the dentate $(\mathrm{n}=124 ; 41.2 \%)$ and edentate $(n=55 ; 40 \%)$ residents, along with dry, sore or cracked lips $33.6 \%$ in dentate and $38.2 \%$ in edentate residents) [13]. On the basis of these results, we can cautiously conclude that half of the NH residents had hypofunction of saliva secretion. These results correspond to those of our research. A statistically higher incidence of the decreased secretion of saliva in $\mathrm{NH}$ patients (56.8\%) than in $\mathrm{FH}$ patients $(41.6 \%)$ was reported in Barczak et al. study. This may be related to various factors such as comorbidities, therapy, or a worse physical fitness and mental agility of $\mathrm{NH}$ residents compared to those living in $\mathrm{FH}[1,2,15,16]$.

The prevalence of xerostomia increases with age and is approximately $30 \%$ in those aged 65 years and older. Drugs i zmniejszeniu wydzielania śliny, z najczęściej występującymi chorobami ogólnoustrojowymi (nadciśnieniem, chorobami serca, cukrzycą i chorobami układu kostno-stawowego) u starszych pacjentów, nie wykazała statystycznie istotnych różnic w tym zakresie (tab. 3).

Statystycznie częściej pacjenci z DR-ów (60\%) nie zgłaszali objawów poczucia depresji w porównaniu z badanymi z DPS-ów $(20,7 \%)$ oraz statystycznie częściej u badanych z DPS-ów wykazywano poczucie depresji o rosnącym nasileniu (79,3\%) niż z DR-ów (40\%) - tabela 4.

Ponadto przeanalizowano zależność między występowaniem poczucia depresji u pacjentów z DPS-ów i DR-ów, którzy odpowiedzieli twierdząco na pytania 4, 5, 6 i 9 testu Foxa. Nie odnotowano statystycznie istotnych różnic w tym zakresie. Pacjenci z DR-ów stanowili większy odsetek osób, które w GDS uzyskały 0-10 pkt., natomiast wśród badanych, którzy uzyskali 11-15 pkt. w tej skali, dominowali pacjenci z DPS-ów (tab. 5). Pacjenci z DPS-ów, charakteryzujący się gorszym stanem psychicznym, częściej skarżyli się na odczucie suchości w jamie ustnej. Nie była to jednak różnica istotna statystycznie.

\section{DYSKUSJA}

Wyniki badań Stawskiej, która badała 135 pensjonariuszy (w wieku 66-87 lat) DPS-ów ze Szczecina i okolic (Polska), wykazały, że 62,9\% ankietowanych pacjentów skarżyło się na suchość jamy ustnej [12]. Rezultaty te korespondują z powyższymi wynikami, w których stwierdzono występowanie hipofunkcji w wydzielaniu śliny u 56,8\% ankietowanych z DPS-ów. Nieco niższy odsetek osób z suchością jamy ustnej odnotowali Porter i wsp. [13]. Autorzy ci zbadali pensjonariuszy brytyjskich domów 
are the most common cause, as most elderly people take at least one medication that adversely affects salivary function [10]. The survey revealed the occurrence of chronic diseases such as hypertension, heart disease, diabetes, and bone or joint diseases, in $94.7 \%$ of $\mathrm{NH}$ residents and $90.8 \%$ of $\mathrm{FH}$ residents. Nursing homes residents significantly more often $(\mathrm{p}=0.05)$ suffered from high blood pressure, combined with heart disease and diseases of the osteoarticular system, than did those from $\mathrm{FH}-12.3 \%$ and $5.0 \%$ respectively. Viljakainen et al. examined 270 residents (mean age 84.5 ) living in $\mathrm{NH}$ in southern Finland. In their studies, the occurrence of dry mouth with concomitant potential xerostomia risk factor was taken into account [11]. The authors found that $27(10 \%)$ respondents had heart disease with continuous dry mouth, which is 7 times less than the result obtained in the Barczak et al. research. Moreover, in Barczak study, diabetes mellitus was reported more frequently in patients living in $\mathrm{FH}$ than in patients from $\mathrm{NH}$, and the results were respectively $24.2 \%$ and $18.6 \%$. Additionally, hyposalivation was observed in $100 \%$ of $\mathrm{NH}$ patients and $77.7 \%$ of FH patients with diabetes mellitus. Viljakainen et al. reported the occurrence of diabetes with a constant dry mouth in $15(5.6 \%)$ surveyed patients [11]. These results contradict the results obtained by Malicka et al., who surveyed 156 patients with type-1 or type-2 diabetes (mean age: type-1 diabetes 37.5 years; type-2 diabetes 65.0 ). In $24.7 \%$ of patients with type- 1 or type-2 diabetes, hyposalivation was observed [8]. The conflict between the results of these studies and ours may be related to various biological, environmental and other factors, including age, place of residence, and group size.

Zengin et al. examined oral hygiene and oral flora in psychiatric patients in Turkey [17]. The study involved 100 patients (69 men and 31 women) with different psychiatric illnesses living in a NH (age 19-96 years, median: 48 years). Information from patient questionnaires and oral examination findings showed 56 patients with xerostomia. Chronic psychiatric patients need to take medications for long periods. One adverse effect of such medications is xerostomia, which frequently impairs oral health. Xerostomia can cause problems with speaking, chewing, swallowing, wearing dentures, dental caries, and oral infections.

In the same study, more than half of the patients complained of xerostomia. Moreover, most patients had oral infections [17]. This suggested that these patients have frequent oral infections because they have insufficient oral hygiene, and are thus deprived of the protective effects of saliva. The average age of these patients was approximately 50 years. In addition, the biochemical, immunological and microbiological changes that may occur in the composition of saliva as the result of medication, decreases the quality of saliva and increases the risk of infection [17].

Viljakainen et al. examined patients living in $\mathrm{NH}$ who also showed symptoms of depression (as assessed by GSD) and suffered from xerostomia. The above-mentioned relationship was observed in $2.8 \%$ of these patients [11]. This value is significantly lower than in the case of the Polish patients from the NH in Szczecin, with respective values of $14 \%$ and $71 \%$. Depression opieki w wieku 65-100 lat. Badanych podzielono na 2 grupy ze względu na obecność lub całkowity brak uzębienia [13]. Suchość jamy ustnej zaobserwowano zarówno u osób z zębami ( $\mathrm{n}=124$; $41,2 \%)$, jaki u pacjentów nieposiadających uzębienia ( $\mathrm{n}=55 ; 40 \%)$, czemu towarzyszył symptom suchych, bolących i popękanych ust (33,6\% u osób z uzębieniem; 38,2\% u osób bez uzębienia) [13].

Na podstawie cytowanych powyżej wyników można ostrożnie wnioskować, że połowa mieszkańców DPS-ów miała hipofunkcję wydzielania śliny. Wyniki te są zbieżne z wynikami badania Barczak i wsp., w których stwierdzono statystycznie częstsze występowanie zmniejszenia wydzielania śliny u pacjentów z DPS-ów (56,8\%) niż u pensjonariuszy z DR-ów (41,6\%). Może być to związane z takimi czynnikami, jak: współistniejące schorzenia ogólne i terapia z nimi związana oraz gorsza sprawność fizyczna i psychiczna pensjonariuszy DPS-ów w porównaniu do osób zamieszkujących DR [1, 2, 15, 16].

Częstość występowania kserostomii wzrasta wraz z wiekiem i wynosi ok. 30\% u osób w wieku 65 lat i starszych. Najczęstszą przyczyną są leki, bowiem większość osób starszych przyjmuje co najmniej 1 lek, który niekorzystnie wpływa na funkcję śliny [10]. Na podstawie badania ankietowego stwierdzono występowanie 1 lub kilku chorób przewlekłych (nadciśnienie, choroby serca, cukrzyca, choroby układu kostno-stawowego) u 94,7\% osób zamieszkujących DPS-y i u 90,8\% osób zamieszkujących DR-y. Statystycznie istotnie częściej (p = 0,05) pensjonariusze DPS-ów chorowali na nadciśnienie, przy czym jednocześnie występowały u nich choroby serca i choroby układu kostno-stawowego, niż osoby z DR-ów - odpowiednio $12,3 \%$ i $5 \%$. Viljakainen i wsp. przebadali 270 pensjonariuszy (średnia wieku 84,5 lat) zamieszkujących DPS-y w południowej Finlandii. W badaniach tych wzięto pod uwagę występowanie suchości jamy ustnej wraz z współistniejącymi potencjalnymi czynnikami ryzyka kserostomii [11]. Okazało się, że 27 (10\%) ankietowanych zadeklarowało występowanie u nich chorób serca wraz z ciągłą suchością jamy ustnej. Jest to wynik 7 razy mniejszy w porównaniu do rezultatów uzyskanych przez Barczak i wsp. Ponadto w badaniach własnych występowanie cukrzycy odnotowano częściej u pacjentów zamieszkujących DR-y niż u pacjentów z DPS-ów (odpowiednio 24,2\% i 18,6\%). Jednocześnie hipofunkcję w wydzielaniu śliny stwierdzono u 100\% pacjentów z DPS-ów i 77,7\% pacjentów z DR-ów chorujących na cukrzycę. Viljakainen i wsp. odnotowali występowanie cukrzycy wraz ze stałą suchością jamy ustnej u 15 (5,6\%) ankietowanych pacjentów [11]. Wyniki te nie są zbieżne z rezultatami uzyskanymi przez Malicką i wsp., którzy objęli badaniem ankietowym 156 osób z cukrzycą typu I i II (średnia wieku: diabetycy I typu - 37,5 lat; diabetycy II typu - 65 lat). U 24,7\% osób z cukrzycą typu I lub II stwierdzono jednocześnie objawy hipofunkcji w wydzielaniu śliny [8]. Na rozbieżności wyników własnych oraz cytowanych wyżej prac mogły mieć wpływ różne liczebności badanych grup, ich wiek oraz miejsce zamieszkania.

Zengin i wsp. zbadali higienę jamy ustnej i ocenili stan jej flory u pacjentów psychiatrycznych w Turcji [17]. W badaniu wzięło udział 100 osób (69 mężczyzn i 31 kobiet) z różnymi chorobami psychicznymi, którzy mieszkali w domu opieki. 
can lead to less energy being available for self-care, and this can impair oral hygiene and health; poor oral health may also lower psychological well-being and so induce depressive symptoms. Whether depression can have an influence on salivary secretion as suggested is still unclear $[17,18,19]$.

During treatment of patients suffering from such ailments, it is extremely important to pay attention to hygiene of both the oral cavity and of dentures, avoid alcohol and other stimulants, drink a lot of water, and a proper diet. Patients should be informed of the need to follow medical recommendations, including pharmacotherapy, and to monitor its progress. This particular group of patients should be aware of the possibility of using artificial saliva substitutes, or toothpastes intended for patients with a dry mouth $[20,21,22]$.

\section{CONCLUSIONS}

1. The symptoms of dry mouth were not related to the diagnosed systemic diseases in respondents from either group.

2. The residents of $\mathrm{NH}$ were characterized by worse mental state than the examined residents of FH.

3. Dry mouth was more frequent in residents of NH than in residents of $\mathrm{FH}$.

4. Residents of the NH exhibiting poor mental state more often complained of dry mouth sensation.
Pacjenci z badanej grupy byli $\mathrm{w}$ wieku 19-96 lat (mediana $=48$ lat). Uzyskano informacje z kwestionariuszy oraz wywiadów od 56 pacjentów. Osoby z przewlekłymi chorobami psychiatrycznymi muszą przyjmować leki przez długi czas. Negatywnym skutkiem ich działania jest kserostomia, która często pogarsza stan zdrowia jamy ustnej i może powodować problemy z mówieniem, żuciem, połykaniem, noszeniem protez, próchnicą oraz często prowadzi do infekcji jamy ustnej.

W badaniu Zengin i wsp. ponad połowa pacjentów skarżyła się na kserostomię. Co więcej, u większości z nich występowały infekcje jamy ustnej [17], prawdopodobnie związane z niewystarczającą higieną jamy ustnej, co prowadzi do braku ochronnego działania śliny. Średni wiek badanych pacjentów wynosił ok. 50 lat. Ponadto zmiany biochemiczne, immunologiczne lub mikrobiologiczne, mogące wystąpić w ślinie na skutek zażywania leków, obniżają jej jakość i zwiększają ryzyko zakażenia $[17,18,19]$. Viljakainen i wsp. zbadali pacjentów zamieszkujących DPS-y, którzy jednocześnie manifestowali symptomy depresji (oceniane wg GSD) oraz cierpieli na kserostomię. Powyższą zależność odnotowano u 2,8\% zbadanych [11]. Jest to wartość zdecydowanie mniejsza niż ta, którą uzyskano, badając pacjentów szczecińskich domów opieki społecznej (14-71\%). Zarówno depresja może upośledzać higienę jamy ustnej i zdrowie, jak i słaby stan zdrowia jamy ustnej może obniżać kondycję psychiczną pacjenta i wywoływać objawy depresyjne. Nie wiadomo również, czy depresja może wpływać na wydzielanie śliny, jak sugerowano [17].

Podczas planowania leczenia oraz podjęcia go u pacjentów z takimi dolegliwościami należy zwrócić im uwagę na: znaczenie higieny jamy ustnej oraz uzupełnień protetycznych, unikanie alkoholu i innych używek, spożywanie dużej ilości płynów, stosowanie odpowiedniej diety, konieczność wykonywania zaleceń lekarskich odnośnie farmakoterapii i okresowym kontrolowaniu jej przebiegu lub nawet o ewentualnym stosowaniu substytutów sztucznej śliny lub past do zębów przeznaczonych dla pacjentów z problemami suchości w jamie ustnej $[20,21,22]$.

\section{WNIOSKI}

1. Objawy suchości w jamie ustnej nie były związane ze współwystępującymi chorobami ogólnymi u badanych osób z obu grup.

2. Pacjenci z DPS-ów charakteryzowali się gorszym stanem psychicznym niż badani z DR-ów.

3. U pensjonariuszy DPS-ów częściej występowała suchości jamy ustnej niż u osób z DR-ów.

4. Pacjenci z DPS-ów, którzy charakteryzowali się gorszym stanem psychicznym, częściej skarżyli się na odczucie suchości w jamie ustnej. 


\section{REFERENCES / PIŚMIENNICTWO}

1. Kaczmarek U. Leczenie suchości jamy ustnej- przegląd piśmiennictwa. Czas Stomatol 2007;60(2):88-95.

2. Kaczmarek U. Suchość jamy ustnej - etiologia, częstość występowania rozpoznanie - na podstawie piśmiennictwa. Czas Stomatol 2007;60(1):20-31

3. Fox PC, van der Ven PF, Sonies BC, Weiffenbach JM, Baum JB. Xerostomia: evaluation of a symptom with increasing significance. J Am Dent Assoc 1985;110(4):519-25.

4. Pręgiel B, Wrzyszcz-Kowalczyk A, Jankowska K, Bujwid-Jagielska I. Kserostomia jako ważny problem zdrowotny ludzi starszych. Porad Stomatol 2005;5(1):48-51.

5. Filip R, Huk J. Starzenie się układu pokarmowego. Część II: Zaburzenia funkcji wydzielniczych, trawienia i wchłaniania. Geriatria 2008;2:224-30.

6. Srebrzyńska-Witek A, Koszowski R. Wpływ menopauzy na ślinianki i błonę śluzową jamy ustnej. Prz Menopauz 2013;5:423-8.

7. Miller A, Miller I, Kurnatowska A, Rabe-Jabłońska J. Zaburzenia sekrecji śliny jako efekt uboczny farmakologicznego leczenia zaburzeń psychicznych - przegląd piśmiennictwa. Post Psychiatr Neurol 2006;15(1) 29-34.

8. Malicka B, Kaczmarek U, Skośkiewicz-Malinowska K. Prevalence of xerostomia and the salivary flow rate in diabetes patients. Adv Clin Exp Med 2014;23(2):225-33.

9. Fox PC, Busch KA, Baum BJ. Subjective reports of xerostomia and objective measures of salivary gland performance. J Am Dent Assoc 1987;115(4):581-4

10. Gupta A, Epstein JB, Sroussi H. Hyposalivation in elderly patients. J Can Dent Assoc 2006;72(9):841-6.

11. Viljakainen S, Nykänen I, Ahonen R, Komulainen K, Suominen AL, Hartikainen $S$, et al. Xerostomia among older home care clients. Community Dent Oral Epidemiol 2016;44(3):232-8
12. Stawska B. Stomatologia geriatryczna - potrzeby, problemy i oczekiwania stomatologiczne pensjonariuszy Domów Pomocy Społecznej. Ann Acad Med Stetin 2006;52(2):89-97.

13. Porter J, Ntouva A, Read A, Murdoch M, Ola D, Tsakos G. The impact of oral health on the quality of life of nursing home residents. Health Qual Life Outcomes 2015;13:102.

14. Yesavage JA, Brink TL, Rose TL, Lum O, Huang V, Adey M, et al. Development and validation of a geriatric depression screening scale: a preliminary report. J Psychiatr Res 1982-1983;17(1):37-49.

15. Barczak K, Szmidt M, Buczkowska-Radlińska J. Funkcjonalność narządu żucia a poczucie depresji u pacjentów po 55. roku życia zamieszkałych w środowisku rodzinnym i w domach pomocy społecznej. Psychiatr Pol 2016;50(5):1027-38.

16. Tanasiewicz M, Hildebrandt T, Obersztyn I. Xerostomia of various etiologies: a review of the literature. Adv Clin Exp Med 2016;25(1):199-206.

17. Zengin AZ, Yanik K, Celenek P, Unal-Erzurumlu Z, Yilmaz H, Bulut N. Oral hygiene and oral flora evaluation in psychiatric patients in nursing homes in Turkey. Niger J Clin Pract 2015;18(6):751-6.

18. Winkler S, Garg AK, Mekayarajjananonth T, Bakaeen LG, Khan E. Depressed taste and smell in geriatric patients. J Am Dent Assoc 1999;130(12): 1759-65.

19. Cohen B, Thomson H. Dental care for the elderly. Chicago, London: Boca Raton; 1986. p. 70-8.

20. Jackiewicz-Barańska D, Kamysz E, Mackiewicz Z. Sztuczna ślina. Pol J Cosmetol 2007;10(2):80-90.

21. Gil-Montoya JA, Silvestre FJ, Barrios R, Silvestre-Rangil J. Treatment of xerostomia and hyposalivation in the elderly: a systematic review. Med Oral Patol Oral Cir Bucal 2016;21(3):e355-66.

22. Barczak K. Stan zębów i przyzębia u seniorów z domów pomocy społecznej i domów rodzinnych w województwie zachodniopomorskim. Ann Acad Med Stetin 2011;57(2):104-9. 